\title{
Performance of Eastern Mediterranean Region laboratories in the World Health Organization external quality assessment programme for arbovirus diagnostics
}

Raynal C. Squires, ${ }^{1}$ Christopher J. Oxenford, ${ }^{2}$ Sebastien Cognat ${ }^{2}$ and Frank Konings

${ }^{1}$ World Health Organization Regional Office for the Eastern Mediterranean, Cairo, Egypt. ${ }^{2}$ World Health Organization, Lyon, France. (Correspondence to: Raynal C. Squires: squiresr@who.int).

\begin{abstract}
Background: Arboviruses such as dengue virus, yellow fever virus, Zika virus and chikungunya virus are major threats to human health globally, including countries in the Eastern Mediterranean Region (EMR).

Aims: This study aimed to assess laboratory proficiency in EMR countries for detection of dengue virus, yellow fever virus, Zika virus and chikungunya virus.

Methods: A global external quality assessment programme for arbovirus diagnostics was developed and run in 2016 and 2018. National-level public health laboratories were instructed to apply the polymerase chain reaction detection method on specimen panels containing dengue virus, yellow fever virus, Zika virus and chikungunya virus.

Results: Over both rounds of the programme, $100 \%$ of participating EMR laboratories correctly detected yellow fever virus and chikungunya virus, $\geq 84.6 \%$ detected dengue fever virus and $\geq 76.9 \%$ detected Zika virus.

Conclusion: While participating EMR countries demonstrated good proficiency in detecting arboviruses, only half of them were enrolled in the global external quality assessment programme, providing an incomplete picture of regional capacity. Effort should be put into increasing participation in subsequent rounds.
\end{abstract}

Keywords: arbovirus, diagnostics, quality, laboratory, assessment

Citation: Squires RC; Oxenford CJ; Cognat S; Konings F. Performance of Eastern Mediterranean Region laboratories in the World Health Organization external quality assessment programme for arbovirus diagnostics. East Mediterr Health J. 2020;26(5):616-619. https://doi.org/10.26719/emhj.20.015

Received: 11/11/19; accepted: 01/04/20

Copyright (C) World Health Organization (WHO) 2020. Open Access. Some rights reserved. This work is available under the CC BY-NC-SA 3.0 IGO license (https://creativecommons.org/licenses/by-nc-sa/3.o/igo).

\section{Introduction}

Arboviruses spread by Aedes mosquitoes, particularly flaviviruses like dengue virus (DENV), yellow fever virus (YFV) and Zika virus (ZIKV), and alphaviruses like chikungunya virus (CHIKV), are major threats to human health worldwide. Several countries in the World Health Organization (WHO) Eastern Mediterranean Region (EMR) have been affected. Since 2005, chikungunya outbreaks have been reported in Djibouti, Pakistan, Sudan, and Yemen (1); dengue outbreaks have occurred in Djibouti, Egypt, Pakistan, Saudi Arabia, Somalia, Sudan and Yemen (2); the first-ever incidence of autochthonous transmission occured in Oman in 2019 (3); and Sudan has experienced multiple yellow fever outbreaks (4). Zika virus disease has seemingly not made its way to the Region, although the Aedes vectors are present in the countries mentioned and suitable habitats may be found in several of the Region's other countries (5).

Laboratory detection and characterization of arboviruses is key to diagnosis, clinical and environmental intervention, and epidemiological study. An external quality assessment programme (EQAP) is a means for laboratories to independently demonstrate adequate testing proficiency and detect deficiencies. WHO recently developed a global EQAP for arbovirus diagnostics to determine proficiency in countries in order to adequately detect the priority alpha- and flaviviruses, CHIKV, DENV, YFV and ZIKV. The first round of this global EQAP took place in 2016 as a continuation and global expansion of an EQAP initially developed in the WHO Western Pacific Region (6). Here we summarize the performance of laboratories in the EMR in the first (2016) and second (2018) rounds of the WHO global EQAP for arbovirus diagnostics.

\section{Methods}

The WHO EQAP for arbovirus diagnostics was implemented by the Royal College of Pathologists of Australasia Quality Assurance Programs (RCPAQAP), Australia. It assessed laboratory proficiency to detect DENV, CHIK, ZIKV and YFV (supplementary) by polymerase chain reaction (PCR). The core arbovirus panel consisted of 12 specimens of inactivated, lyophilized DENV, CHIKV, ZIKV, Japanese encephalitis virus (JEV) and either West Nile virus (WNV) or YFV (2016) or tick-borne encephalitis virus (TBEV, 2018). Two of the specimens were double spiked to simulate co-infection. Specimens were tested for homogeneity and stability and verified at referee laboratories. The supplementary 5-specimen YFV strain 
panel was similarly prepared. The 2018 round of the EQAP additionally offered a serological specimen panel for anti-DENV antibody detection, but this is not examined here. Panels were distributed to participating national-level public health laboratories between October and December.

All participants were requested to report the absence or presence of DENV, CHIKV and ZIKV (and YFV, if relevant) in each specimen by PCR. Optionally, they could report the absence or presence of other alpha- and flaviviruses, perform DENV serotyping, or identify ZIKV lineage. Participants were assigned code numbers for confidentiality, which is maintained in any subsequent reporting by WHO and RCPAQAP. Participants received individual performance reports in March of the following year. Global reports were shared shortly thereafter.

\section{Results}

In 2016, 96 laboratories participated in the programme globally including 9 laboratories from 7 countries $^{1}$ in the EMR. Of the EMR laboratories, 100\% (6/6) correctly identified CHIKV each time it was present, 100\% (5/5) correctly identified YFV, and 87.5\% (7/8) correctly identified DENV and ZIKV (Figure 1). Four testing errors were observed in this round of the EQA, evenly distributed among specimens, but primarily (3/4) committed by a single laboratory. PCR diagnostics for DENV, CHIK, ZIKV and YFV were available in 5 laboratories. JEV and WNV mostly went undetected as several laboratories did not test for them and instead only reported the absence or presence of the other viruses. One laboratory chose to perform an optional test, DENV serotyping, and did so with $100 \%$ accuracy.

In the second (2018) round of the EQAP, 107 laboratories participated globally. Thirteen, including 5 repeat participants, represented 11 EMR countries ${ }^{2}$. Of the EMR laboratories, 100\% (6/6) correctly identified YFV, 100\% (11/11) identified CHIKV, 84.6\% (11/13) identified DENV and $76.9 \%$ (10/13) identified ZIKV (Figure 1). Of the 5 repeat participants, $100 \%(5 / 5)$ accurately detected CHIKV in each round, $\geq 75 \%$ (3/4 in $2016,4 / 5$ in 2018) accurately detected DENV and $\geq 60 \%$ (4/5 in 2016, 3/5 in 2018) accurately detected ZIKV. Note that one of the laboratories did not test for DENV in 2016. A smaller subset of 3 repeat participants tested for YFV in each round and did so correctly. Most errors (4/6) in the 2018 round were observed in a single DENV-ZIKV double-spiked specimen: 3 false negatives made by 2 laboratories and a clerical error by a third. However, the false negatives appeared to be coincidental as referee laboratories did not flag the specimen as problematic (defective specimens are withdrawn from scoring in EQAPs). The laboratory with the most errors in 2016 made none in 2018. PCR diagnostics for DENV, CHIK, ZIKV and YFV were available in 6 laboratories. Similar to 2016,

Figure 1 Proficiency of laboratories in the WHO EMR participating in the global EQAP for arbovirus diagnostics, 2016 and 2018

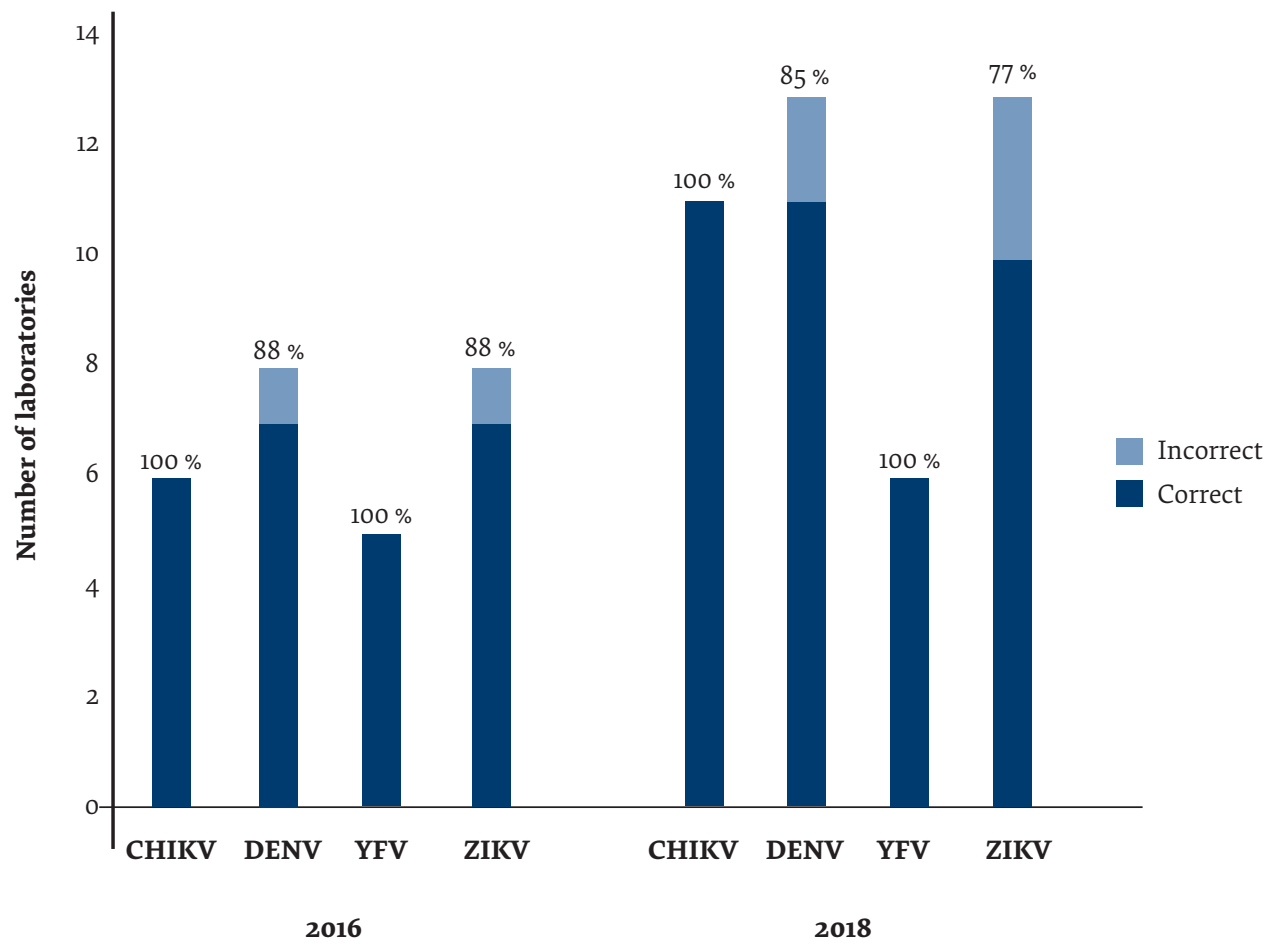

$C H I K V=$ chikunguny a virus; $D E N V=$ dengue virus; $E M R=E a s t e r n$ Mediterranean Region; EQAP= external quality assessment programme; YVF=yellow fever virus; ZIKV=Zika virus

2016: Egypt, Islamic Republic of Iran, Morocco, Oman, Saudi Arabia, Sudan and Tunisia.

2018: Bahrain, Egypt, Islamic Republic of Iran, Jordan, Kuwait, Lebanon, Morocco, Oman, Pakistan, Tunisia and United Arab Emirates. 
laboratories reported solely on the absence or presence of DENV, CHIK, ZIKV and YFV, leaving the additional viruses (JEV and TBEV) undetected. DENV serotyping was again the only optional test chosen in 2018, this time by $5 / 13$ laboratories that all performed the assay correctly.

\section{Discussion}

Although WHO invited roughly the same number of EMR countries in both years, almost double the number participated in 2018 compared to 2016. Participation is increased through WHO's direct interactions with, and encouragement of, targeted laboratories or through general advocacy efforts such as laboratory network meetings, trainings or publications (7). Participation nevertheless is voluntary and, particularly in the EMR, may at times be impacted by crises, limited resources, imposed sanctions and challenges with customs authorities. Four of the laboratories from 2016 could not join the second round. Participation of three of these, all from one country, was declined by the government in 2018 until a new national laboratory started to function. The fourth laboratory signed up but sanctions ultimately prevented RCPAQAP from working with couriers to deliver the EQAP panel to them.

EMR laboratories demonstrated good proficiency in arbovirus detection. In both EQAP rounds, $\geq 84.6 \%$ of laboratories accurately tested for DENV, CHIKV and YFV while $\geq 76.9 \%$ accurately tested for ZIKV. A minority of laboratories both years neglected to provide information supporting their results, such as assays used, target sequences or number of PCR cycles ran. Such incomplete recording hinders the EQAP organizer's ability to identify problematic areas and relay this information back in order to allow the relevant laboratories to take corrective actions.
While the EMR laboratories participating in the 2016 and 2018 rounds of the EQAP demonstrated good proficiency, they represent only half of the countries in the Region, providing an incomplete picture of national capacities for arbovirus diagnostics. In addition, few countries with arbovirus outbreaks have consistently, or ever, participated. For some this is due to conflict, other priorities or difficulty in sourcing the necessary reagents. WHO helps countries in the region obtain arbovirus diagnostic reagents and protocols as needed, as well as facilitates regional and in-country trainings to build laboratory capacity for arbovirus detection for preparedness or during emergency response. WHO will continue to assist where it can as well as encourage the enrolment of more countries in the programme to ensure that quality testing for arboviruses is available in the Region.

\section{Conclusion}

Arboviral infections continue to have an impact on countries in the EMR region, making it essential that national-level public health laboratories be able to adequately detect these pathogens. The EQAP for arbovirus diagnostics is an important measure of the ability of these laboratories to accomplish this and they have demonstrated good performance in the two rounds of the programme conducted thus far. Weak points revealed through the programme offer laboratories (and WHO, as needed) the opportunity to implement corrective actions to improve the quality of testing available. As EMR country representation in the programme still leaves room for improvement, particularly from countries with arbovirus disease outbreaks, WHO will endeavour to advocate for greater participation in upcoming rounds.

Funding: None.

Comepeting interests: None declared.

\section{Performance des laboratoires de la Région de la Méditerranée orientale dans le cadre du programme d'évaluation externe de la qualité de l'Organisation mondiale de la Santé en matière de diagnostic des arbovirus \\ Résumé}

Contexte : Les arbovirus tels que le virus de la dengue, le virus de la fièvre jaune, le virus Zika et le virus chikungunya constituent des menaces majeures pour la santé humaine dans le monde, y compris dans les pays de la Région de la Méditerranée orientale.

Objectifs : La présente étude visait à évaluer l'aptitude des laboratoires dans les pays de la Région pour la détection des virus susmentionnés.

Méthodes : Un programme mondial d'évaluation externe de la qualité pour le diagnostic des arbovirus a été mis au point et adopté en 2016 et 2018. Les laboratoires de santé publique nationaux ont reçu l'instruction d'appliquer la méthode de détection par amplification génique sur des panels d'échantillons de laboratoires contenant le virus de la dengue, le virus de la fièvre jaune, le virus Zika et le virus chikungunya.

Résultats : Au cours des deux cycles du programme, $100 \%$ des laboratoires participants de la Région de la Méditerranéenne orientale ont correctement détecté le virus de la fièvre jaune et le virus du chikungunya, un pourcentage supérieur ou égal à $84,6 \%$ ont détecté le virus de la dengue et un pourcentage supérieur ou égal à 76,9\% de ces laboratoires ont détecté le virus Zika.

Conclusions : Alors que les pays participants de la Région de la Méditerranée orientale ont démontré une bonne maîtrise de la détection des arbovirus, seulement la moitié d'entre eux étaient inscrits au programme mondial d'évaluation externe de la qualité, fournissant une image incomplète de la capacité régionale. Des efforts devraient être déployés pour accroître la participation aux cycles suivants. 
أداء غختبرات إقليم شرق المتوسط في برنامج تقييم الجودة الخارجي لمنظمة الصحة العالمية لتشخيص الفيروسات المنقولة بالمفصليات

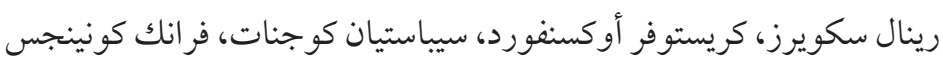

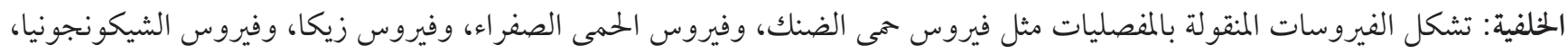

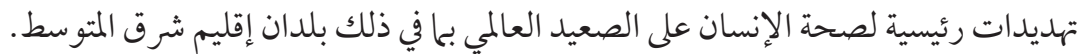

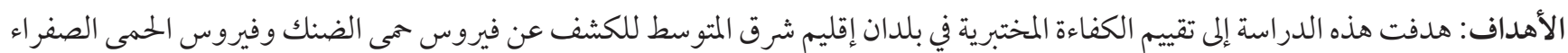
وفيروس زيكا وفيروس الشيكونجونيا.

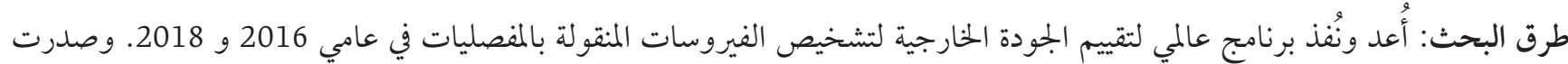

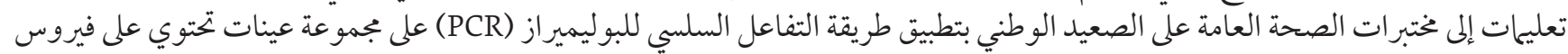
حمى الضنك، وفيروس الحمى الصفراء، وفيروس زيكا، وفيروس الشيكونجين الصنيف الصنيا.

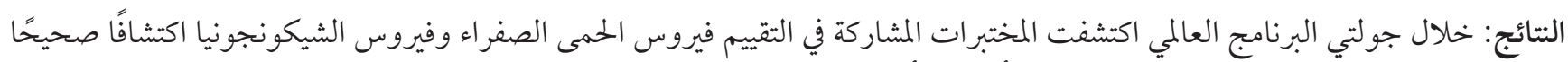

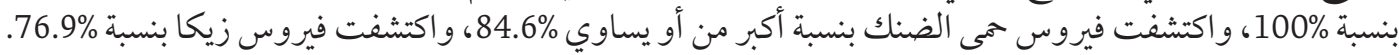

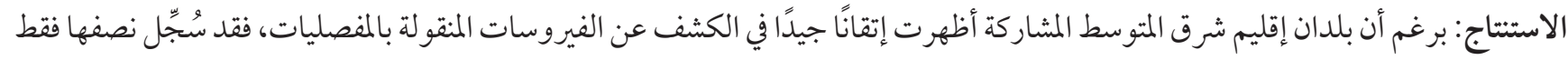

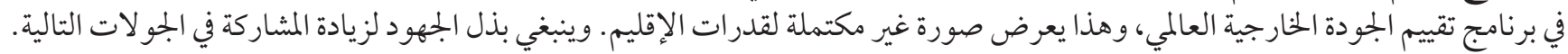

\section{References}

1. Humphrey JM, Cleton NB, Reusken CB, Glesby MJ, Koopmans MP, Abu-Raddad LJ. Urban chikungunya in the Middle East and North Africa: a systematic review. PLoS Negl Trop Dis. 2017; 11(6):e0005707.

2. Humphrey JM, Cleton NB, Reusken CBEM, Glesby MJ, Koopmans MPG, Abu-Raddad LJ. Dengue in the Middle East and North Africa: A Systematic Review. PLoS Negl Trop Dis. 2016; 10: e0005194.

3. World Health Organization. Weekly Epidemiological Monitor. 2019; 12(3): 3 (http://applications.emro.who.int/docs/epi/2019/ Epi_Monitor_2019_12_3.pdf, accessed 31 October 2019)

4. World Health Organization. Weekly Epidemiological Monitor. 2013; 6(50):50 (http://applications.emro.who.int/dsaf/epi/2013/ Epi_Monitor_2013_6_50.pdf, accessed 31 October 2019)

5. Ducheyne E, Minh NN, Haddad N, Bryssinckx W, Buliva E, Simard F et al. Current and future distribution of Aedes aegypti and Aedes albopictus (Diptera: Culicidae) in WHO Eastern Mediterranean Region. Int J Health Geogr. 2018; 17(1):4.

6. Abdad MY, Squires RC, Cognat S, Oxenford CJ, Konings F. External quality assessment for arbovirus diagnostics in the World Health Organization Western Pacific Region, 2013-2016: improving laboratory quality over the years. Western Pac Surveill Response J. 2017; 8:27.

7. Epidemic and pandemic-prone diseases | News. World Health Organization Regional Office for the Eastern Mediterranean; 2017 (http://www.emro.who.int/pandemic-epidemic-diseases/news/regional-training-workshop-held-on-zika-virus-diagnostics.html, accessed 27 January 2020) 